\title{
Penentuan Proses Pretreatment untuk Pemanfaatan Limbah Kulit Singkong sebagai Bahan Baku Bioetanol melalui Hidrolisa Enzimatis menggunakan Aspergillus spp.
}

\author{
Dessy Ariyanti ${ }^{1 *}$, Aprilina Purbasari ${ }^{1}$, Heny Kusumayanti ${ }^{2}$, Noer Abyor Handayani ${ }^{1}$ \\ ${ }^{1}$ Departemen Teknik Kimia, Fakultas Teknik, Universitas Diponegoro \\ ${ }^{2}$ Program Studi Teknik Kimia, Departemen Teknologi Industri, Sekolah Vokasi, Universitas Diponegoro \\ Jl. Prof. Soedarto, Tembalang, Kota Semarang, Jawa Tengah 50275, Indonesia \\ Email: dessy.ariyanti@che.undip.ac.id
}

\begin{abstract}
Abstrak
Ketergantungan terhadap bahan bakar fosil ini menjadi masalah besar yang sangat mendesak untuk segera diselesaikan. Salah satu langkah solusi yang bisa dilakukan adalah memanfatkan bioetanol lignoselulosa dari limbah kulit singkong sebagai alternatif pengganti. Permasalahan utama yang menghambat penggunaan kulit singkong sebagai bahan baku utama pembuatan bioetanol adalah belum adanya proses pretreatment dan hidrolisa yang terbukti efektif secara teknis maupun ekonomis untuk mengkonversi lignoselulosa yang terkandung dalam kulit singkong menjadi bentuk gula sederhana. Penelitian ini dilaksanakan untuk mengetahui efektifitas proses pretreatment dan hidrolisa untuk mengkonversi lignoselulosa yang terkandung dalam kulit singkong menjadi bentuk gula sederhana. Metode pretreatment asam $\left(\mathrm{H}_{2} \mathrm{SO}_{4}\right)$ dan organosolv (Etanol $+\mathrm{CH}_{3} \mathrm{COONa}$ ) terbukti dapat meningkatkan yield gula tereduksi hingga $50 \%$ dibandingkan dengan proses hidrolisa tanpa pretreatment. Yield hingga 78\% dapat diperoleh pada proses pretreatment asam suhu $30^{\circ} \mathrm{C}$, waktu 30 menit yang dilanjutkan dengan hidrolisa enzimatik dengan Aspergillus niger selama 48 jam. Peningkatan yield pada proses pretreatment organosolv (optimum $74 \%$ pada suhu $30^{\circ} \mathrm{C}$, waktu 90 menit) masih dapat dilakukan dengan meningkatkan waktu operasi dan meningkatkan suhu operasi. Namun peningkatan suhu maupun penambahan waktu operasi berpengaruh terhadap analisa teknis dan ekonomis dari proses. Secara teknis, pretreatment organosolv lebih mudah dilakukan terutama pada proses dengan kondisi operasi atmosferik dibandingkan dengan pretreatment asam karena sifat bahan kimia yang digunakan dan penanganannya. Secara ekonomis, pretreatment asam lebih baik untuk diaplikasikan dibandingkan pretreatment organosolv, hal ini dikarenakan yield yang dihasilkan lebih tinggi pada kondisi proses atmosferik.
\end{abstract}

Kata kunci: $\mathrm{H}_{2} \mathrm{SO}_{4}$, hidrolisa enzimatis, kulit singkong, organosolv, pre-treatment asam

\section{Abstract \\ Determination of Pretreatment Process for Utilizing Cassava Skin Waste as Bioethanol Raw Material through Enzymatic Hydrolysis using Aspergillus spp.}

Lignocellulose material derived from cassava peel can be utilized as raw material for bioethanol production. The utilization of this material can be part of solution in order to maintain Indonesia's energy security which still majority covered by the fossil fuel. The main problem of lignocellulose conversion into bioethanol is their crystalline structures those make them really difficult to be converted into monomeric sugar prior fermentation to produce ethanol. The objective of this research is to find out the effectiveness of pre-treatment process prior enzymatic hydrolysis of lignocellulose contained on cassava peel. The result shows pre-treatment methods both acid $\left(\mathrm{H}_{2} \mathrm{SO}_{4}\right)$ and organosolv (Etanol $+\mathrm{CH}_{3} \mathrm{COONa}$ ) proved to be effective in order to increase the yield of total reducing sugar (TRS) until 50\% after enzymatic hydrolysis compared to the sample without pre-treatment. 
Highest yield $78 \%$ can be achieved by applying acid pre-treatment under temperature $30^{\circ} \mathrm{C}$ and 30 minutes of process prior enzymatic hydrolysis by Aspergillus niger under temperature $35^{\circ} \mathrm{C}$ for 48 hours. Further optimization in organosolv pre-treatment can be conducted by increasing the temperature and prolong the process into certain extent. It should be noted that the above action could influence the feasibility of the organosolv pre-treatment technically and economically. From technical point of view, organosolv pre-treatment can be more feasible compared to acid pre-treatment (under atmospheric condition) as the reagents are easy to handle in terms of safety consideration. However, from economic side acid pre-treatment is more preferable as higher yield of the process and lower volume of chemical can be used in order to achieve the same amount of product.

Keywords: $\mathrm{H}_{2} \mathrm{SO}_{4}$, enzymatic hydrolysis, cassava peel, organosolv, acid pre-treatment

\section{PENDAHULUAN}

Kebutuhan energi Indonesia saat ini sebagian besar masih bertumpu pada bahan bakar fosil. Kebutuhan total energi nasional tahun 2016 berada pada kisaran 795 juta SBM (setara barrel minyak) (BPPT, 2018). Ketergantungan terhadap bahan bakar fosil ini menjadi masalah besar yang sangat mendesak untuk segera diselesaikan. Salah satu langkah solusi yang bisa dilakukan adalah memanfatkan bioetanol lignoselulosa sebagai alternatif pengganti. Salah satu sumber biomasa lignoselulosa non pangan di Indonesia yang tersedia melimpah adalah limbah kulit singkong. Produksi singkong di Jawa Tengah sekitar 3,18 juta ton dengan luas lahan 120,895 hektar dan produktivitas lahan 259,64 ku/ha (BPS, 2018). Jumlah kulit singkong dari total berat singkong berkisar 20-35\% (Olanbiwoninu \& Odunfa, 2012), sehingga berdasarkan data tahun 2017 dapat diasumsikan bahwa Jawa Tengah menghasilkan 636 - 1,11 juta kulit singkong. Permasalahan utama yang menghambat penggunaan kulit singkong sebagai bahan baku utama pembuatan bioetanol adalah jenis polisakarida yang terkandung dalam kulit singkong tersebut yaitu selulosa dan hemiselulosa. Dalam proses pembuatan bioetanol, selulosa dan hemiselulosa harus dikonversi dalam bentuk gula sederhana yang nantinya difermentasi oleh mikroba untuk menghasilkan bioetanol. Polisakarida jenis selulosa dan hemiselulosa sangat sulit untuk dikonversi menjadi bentuk gula sederhana (glukosa) karena struktur polimernya yang sangat kuat. Penelitian-penelitian yang telah dilaksanakan (Murtianto \& Chandra, 2008; Sathya Geetha \& Krishnan, 2009; Hikmiyati \& Yanie, 2010; Juwita \&
Susilowati, 2011; Artiyani, 2011; Kongkiattikajorn \& Sornvoraweat, 2011; Kongkiattikajorn, 2012) kurang berfokus pada proses konversi selulosa dan hemiselulosa menjadi bentuk gula sederhana. Berdasarkan hal tersebut, maka penelitian ini diarahkan untuk mendapatkan metode pretreatment yang efektif, efesien dan aplikatif serta ekonomis untuk menunjang proses hidrolisa dan dalam mengkonversi selulosa dan hemiselulosa serta polisakarida lain yang terkandung limbah kulit singkong menjadi bentuk gula sederhana yang nantinya dapat digunakan sebagai bahan baku bioetanol.

\section{METODOLOGI}

Bahan baku utama dari penelitian ini adalah limbah kulit singkong dari PT. Indofood Fritolay Semarang. Kulit singkong ini dicuci, dikeringkan dengan sinar matahari kemudian ditepungkan, dikeringkan kembali dalam oven temperatur $55^{\circ} \mathrm{C}$ selama 12 jam untuk kemudian disimpan. Bahan baku lainnya adalah $\mathrm{H}_{2} \mathrm{SO}_{4}$, Etanol, Sodium asetat (Merck) untuk proses pretreatment serta $\mathrm{CaCl}_{2} .7 \mathrm{H}_{2} \mathrm{O}, \mathrm{MgSO}_{4}$, dan $\left(\mathrm{NH}_{4}\right)_{3} \mathrm{PO}_{4}$ (EM) untuk proses hidrolisa enzimatik.

Strain Aspergillus spp (A. niger dan $A$. oryzae) didapatkan dari koleksi Center of Biomass and Renewable Energy (C-BIORE), Jurusan Teknik Kimia, Fakultas Teknik, Universitas Diponegoro. Strain ini disuplai dari Jurusan Pangan dan Nutrisi Universitas Gajah Mada, yang dipindahkan pada slant potato dextrose agar (PDA) dan disimpan pada suhu $4^{\circ} \mathrm{C}$.

Proses diawali dengan pretreatment asam yaitu dengan mensuspensikan $5 \mathrm{gr}$ tepung kulit singkong dalam $45 \mathrm{ml} \quad \mathrm{H}_{2} \mathrm{SO}_{4}$, kemudian 
dipanaskan hingga temperatur sesuai variabel selama 30 menit (variabel waktu). Setelah itu, suspensi disaring, residunya dicuci dengan menggunakan $\mathrm{NaOH}$ untuk menetralkan pHnya. Pretreatment organosolv dilakukan dengan cara yang hampir sama yaitu mensuspensikan $5 \mathrm{gr}$ tepung kulit singkong dalam $45 \mathrm{ml}$ etanol yang sebelumnya telah ditambah $\mathrm{CH}_{3} \mathrm{COONa} 0,05 \mathrm{M}$. Suspensi kemudian dipanaskan hingga temperatur sesuai variabel selama 30 menit. Setelah itu, suspensi disaring, residunya dicuci dengan menggunakan aquades. Hidrolisa enzimatik dilakukan dengan menambahkan $1.5 \% \mathrm{w} / \mathrm{v}$ kulit singkong hasil pretreatment ke dalam $100 \mathrm{ml}$ medium yang terdiri dari $1 \mathrm{~g} / \mathrm{l} \mathrm{CaCl}_{2} .7 \mathrm{H}_{2} \mathrm{O}, 1 \mathrm{~g} / \mathrm{l}$ $\mathrm{MgSO}_{4}, 2 \mathrm{~g} / \mathrm{l} \quad\left(\mathrm{NH}_{4}\right)_{2} \mathrm{SO}_{4}$, and $0.5 \mathrm{~g} / \mathrm{l} \quad \mathrm{KH}_{2} \mathrm{PO}_{4}$. Kemudian medium disterilisasi dan diinokulasi dengan Aspergillus spp. Campuran kemudian diinkubasi selama 48 jam pada temperatur $35^{\circ} \mathrm{C}$. Hasil fermentasi kemudian disentrifugasi untuk diambil supernatannya dan dianalisa.

Hasil penelitian dianalisis supernatannya untuk mengetahui gula tereduksi. Konsentrasi gula tereduksi diestimasi dengan menggunakan metode penentuan gula tereduksi DNS (Andersen, 2007). Analisa teknis dilakukan dengan mencatat fenomena yang terjadi selama proses penelitian berlangsung, terutama mengenai kendala-kendala yang di temui serta membandingkan keuntungan dan kelemahan proses pretreatment asam dan organosolv. Analisa ekonomi dilakukan dengan mengestimasi dari data hasil penelitian yaitu kondisi operasi proses pretreatment dan hidrolisa enzimatik, bahan kimia yang digunakan serta harga dan berapa kuantitas penggunaannya.

\section{HASIL DAN PEMBAHASAN}

\section{Pengaruh proses pretreatment terhadap yield gula tereduksi}

Penelitian ini membandingkan dua jenis metode pretreatment yaitu pretreatment asam $\left(\mathrm{H}_{2} \mathrm{SO}_{4}\right)$ dan pretreatment organosolv (etanol $+\mathrm{CH}_{3} \mathrm{COONa}$ ) yang dilakukan sebelum proses hidrolisa enzimatik. Setelah proses hidrolisa enzimatik menggunakan dua jenis mikroorganisme yaitu Aspergillus niger dan Aspergillus oryzae, efektifitas dari kedua proses pretreatment dalam mengkonversi komponen lignoselulosa menjadi gula sederhana dapat dibandingkan.. Gambar la menunjukkan pretreatment asam dengan $\mathrm{H}_{2} \mathrm{SO}_{4} \quad 0,1 \mathrm{M}$ selama 30 menit pada suhu $30^{\circ} \mathrm{C}$ yang dilanjutkan dengan hidrolisa enzimatik dengan Aspergillus niger selama 48 jam, dapat menghasilkan yield yang lebih tinggi (76\%) dibandingkan dengan pretreatment organosolv (Etanol $+\mathrm{CH}_{3} \mathrm{COONa}$ 0,05M) pada kondisi yang sama (60\%).

Proses pretreatment baik asam maupun organosolv dapat meningkatkan yield gula tereduksi yang dihasilkan (min 40\%) dibandingkan dengan proses hidrolisa enzimatik tepung kulit singkong tanpa pretreatment. Kecenderungan yang sama dapat dilihat pada gambar 1b dimana hidrolisa enzimatik memanfaatkan enzim dari mikroorganisme Aspergillus oryzae. Namun

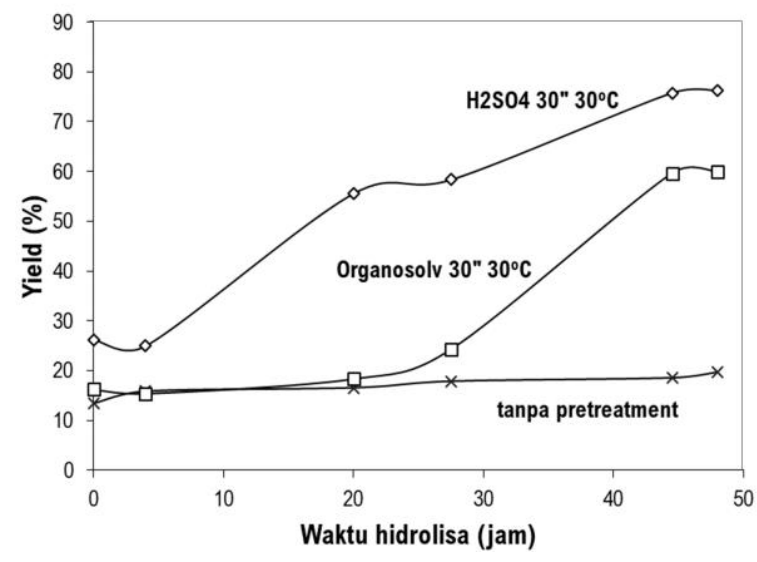

(a)

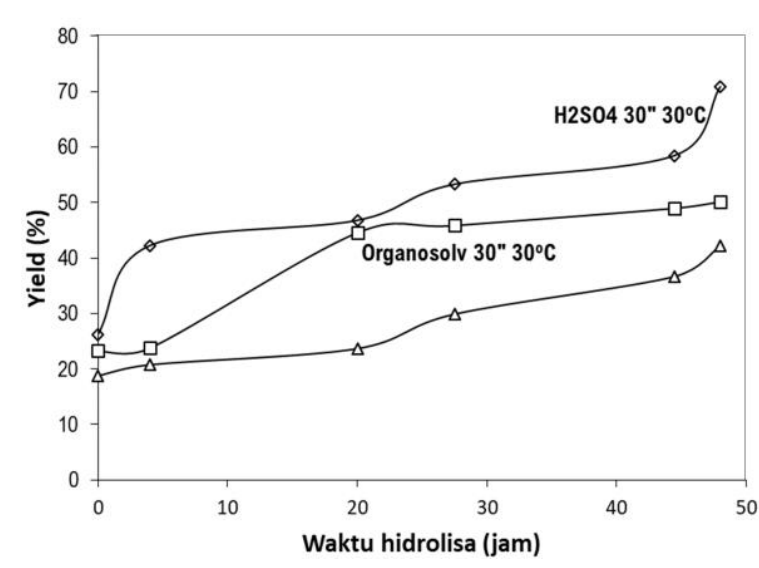

(b)

Gambar 1 Perbandingan hasil gula tereduksi dari berbagai proses pretreatment setelah proses hidrolisa enzimatik dengan Aspergillus niger (a) dan Aspergillus oryzae (b) selama 48 jam 
apabila dibandingkan dengan yield yang dihasilkan dari proses hidrolisa enzimatik tepung kulit singkong tanpa pretreatment, penambahan proses pretreatment baik asam maupun organosolv hanya dapat meningkatkan yield gula tereduksi $10-30 \%$ saja. Parameter utama dari hidrolisa enzimatik adalah terjadinya kontak fisik antara enzim dan ikatan molekul yang akan dihidrolisa. Kontak fisik lebih diterjemahkan pada luas permukaan kontak, kristalinitas substrat, ukuran partikel dan porositas substrat (Andersen, 2007). Pretreatment kimia seperti metode pretreatment asam $\left(\mathrm{H}_{2} \mathrm{SO}_{4}\right)$ berfungsi untuk memutuskan ikatan kristalin dari struktur lignoselulosa. Berkurangnya struktur kristalin memberikan kesempatan kepada enzim yang dihasilkan oleh Aspergillus niger dan oryzae untuk masuk kedalam substrat dan menjadi mediator reaksi hidrolisa. Hal ini terlihat dari adanya perbedaan yang cukup tinggi antara hasil hidrolisa sampel tanpa dan dengan pretreatment. Tren yang sama dikemukakan oleh Zhang et al. (2006) yang menginvestigasi pengaruh metode pretreatment asam $\left(\mathrm{H}_{3} \mathrm{PO}_{4}\right)$ terhadap proses hidrolisa. Terdapat perbedaan hasil hidrolisa yang cukup signifikan antara sampel selulosa tanpa pretreatment dibandingkan dengan sampel selulosa dengan pretreatment asam $\left(\mathrm{H}_{3} \mathrm{PO}_{4}\right)$. Hal ini terjadi karena pretreatment asam dapat merusak struktur kristalin pada substrat dan menyediakan luas permukaan yang lebih luas untuk enzim dalam mengkatalisasi proses hidrolisa (Zhang, et.al 2006). Sementara itu, pretreatment organosolv (Etanol $+\mathrm{CH}_{3} \mathrm{COONa}$ ) berfungsi untuk melarutkan lignin yang merupakan bagian dari material lignoselulosa (1528\%) dan berikatan silang dengan hemiselulosa. Seperti halnya dengan pretreatment asam, terlarutnya lignin dapat menyediakan luas permukaan yang cukup besar kepada enzim dalam mengkatalisasi proses hidrolisa. Selain itu substrat utama yaitu selulosa dan hemiselulosa lebih mudah diakses saat komponen lignin terlarut dalam solven organik dalam hal ini etanol (Zhao, et al., 2009; Zhang et al., 2016).

Data pada gambar 1 juga memperlihatkan pretreatment asam menghasilkan yield gula tereduksi yang lebih tinggi dibandingkan dengan pretreatment organosolv. Hal yang sama didapatkan oleh Olanbiwoninu dan Odunfa (2012) yang menggunakan asam sulfat sebagai bagian dari pretreatment asam sebelum proses hidrolisa enzimatik dengan Pseudomonas fluorescens dan Aspergillus terreus. Asam sulfat dan beberapa jenis asam lainnya menyediakan ion hidrogen tambahan untuk membentuk asam konjugasi, yang membentuk celah pada ikatan glikosidik. Hal ini dapat mendesktruksi ikatan kristalin pada substrat. Molekul air pada sistem juga dapat membantu proses desktruksi ini. Sehingga luas permukaan dan akses yang dibentuk dalam substrat semakin banyak dibandingkan dengan pretreatment organosolv yang hanya mampu melarutkan lignin (Wyman, 2006; Sun, et al., 2016).

\section{Optimasi proses pretreatment}

Dua proses pretreatment yaitu pretreatment asam dan organosolv yang dilakukan sebelum proses hidrolisa enzimatik terbukti dapat meningkatkan yield gula tereduksi (10-50\%) untuk nantinya dapat diproses lebih lanjut hingga menghasilkan etanol. Secara umum terdapat dua parameter utama yang mempengaruhi gula tereduksi yang dihasilkan setelah proses pretreatment yaitu suhu dan lama proses tersebut berlangsung (Gambar 2).

Gambar 2a menunjukkan pengaruh waktu pretreatment terhadap gula tereduksi yang dihasilkan sebelum dan setelah proses hidrolisa enzimatik dengan Aspergillus niger selama 48 jam. Kecenderungan antara pretreatment asam dan organosolv berbeda pada variasi waktu proses. Yield dari bahan baku tepung kulit singkong yang dipretreatment dengan organosolv cenderung meningkat seiring dengan penambahan waktu operasi, sebaliknya yield dari bahan baku tepung kulit singkong yang dipretreatment dengan asam cenderung menurun. Tren yang sama ditemukan pada proses hidrolisa enzimatik dengan Aspergillus oryzae (Gambar 2c).

Parameter lain yang mempengaruhi yield gula tereduksi adalah suhu proses pretreatment. Proses pretreatment asam menggunakan variasi suhu proses $30-90^{\circ} \mathrm{C}$, sementara proses pretreatment organosolv menggunakan variasi suhu $30-60^{\circ} \mathrm{C}$, dikarenakan proses pretreatment organosolv melibatkan etanol yang memiliki titik didih $60^{\circ} \mathrm{C}$. Gambar 2b dan d memperlihatkan pengaruh suhu terhadap gula tereduksi yang dihasilkan sebelum dan setelah proses hidrolisa 
enzimatik dengan Aspergillus niger dan Aspergillus oryzae selama $48 \mathrm{jam}$. Tren yang sama diperoleh dari hasil penelitian dengan kedua jenis mikroorganisme tersebut. Peningkatan suhu proses berpengaruh terhadap peningkatan yield gula tereduksi pada bahan baku yang ditreatment menggunakan organosolv, sedangkan yield gula tereduksi pada bahan baku yang ditreatment menggunakan asam cenderung menurun seiring dengan peningkatan suhu.

Mekanisme pretreatment organosolv dengan etanol dan $\mathrm{CH}_{3} \mathrm{COONa}$ lebih dititik beratkan pada proses pelarutan lignin pada etanol. Proses pelarutan lignin sangat dipengaruhi oleh suhu dan waktu operasi, sehingga semakin tinggi suhu dan waktu operasi, yield gula tereduksi yang dihasilkan juga semakin tinggi (Quesada et al., 2010). Sedangkan, mekanisme yang ditekankan pada proses pretreatment asam menggunakan $\mathrm{H}_{2} \mathrm{SO}_{4}$ adalah mekanisme destruksi struktur kristalin dari komponen lignoselulosa. Waktu dan suhu proses secara umum dapat

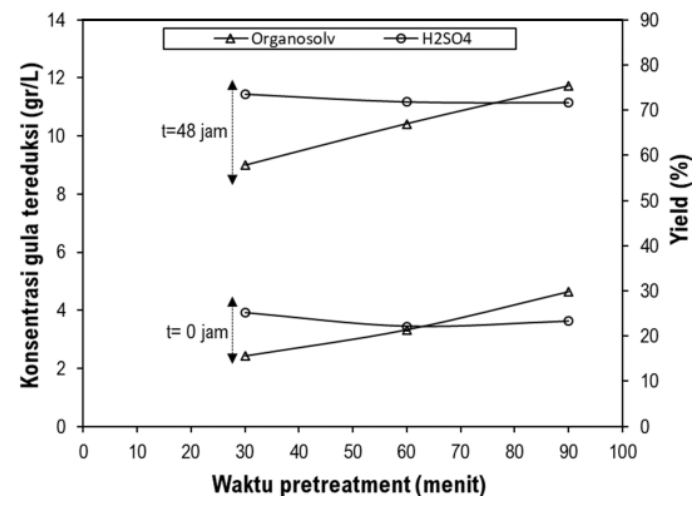

(a)

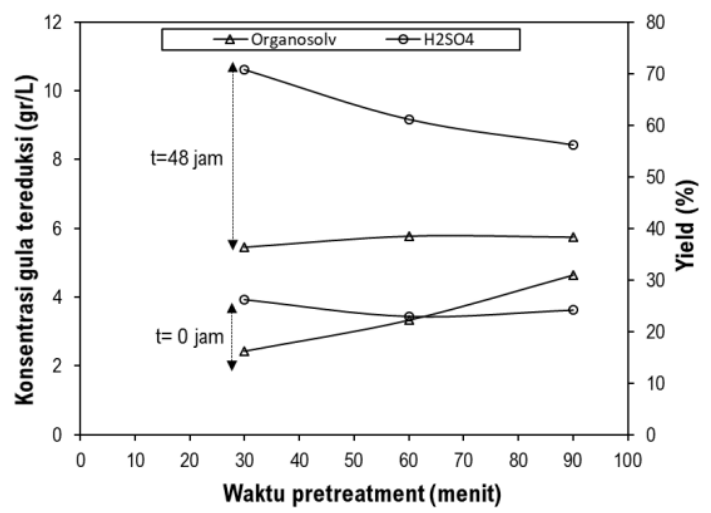

(c) meningkatkan proses dekstruksi kristalin material lignoselulosa (Wyman, 2006; Xu et al., 2015). Namun pada penelitian ini tren yang diamati terbalik, hal ini dimungkinkan akibat proses dekstruksi ini menghasilkan komponen lain selain monomer gula yang mempengaruhi proses hidrolisa enzimatik. Penelitian lebih lanjut mengenai komponen-komponen yang dihasilkan setelah proses pretreatment diperlukan untuk menjelaskan fenomena ini.

\section{Analisis teknis dan ekonomis proses pretreatment}

Dua metode pretreatment yang telah diteliti masing-masing memiliki kelebihan dan kekurangan yang dianalisa selama proses penelitian. Proses pretreatment asam, melibatkan bahan kimia asam sulfat yang sangat berbahaya sedangkan proses pretreatment organosolv melibatkan bahan kimia yaitu etanol yang cukup mahal. Tinjauan teknis dan ekonomis dari kedua proses dapat dilihat pada Table 1 dan 2 .

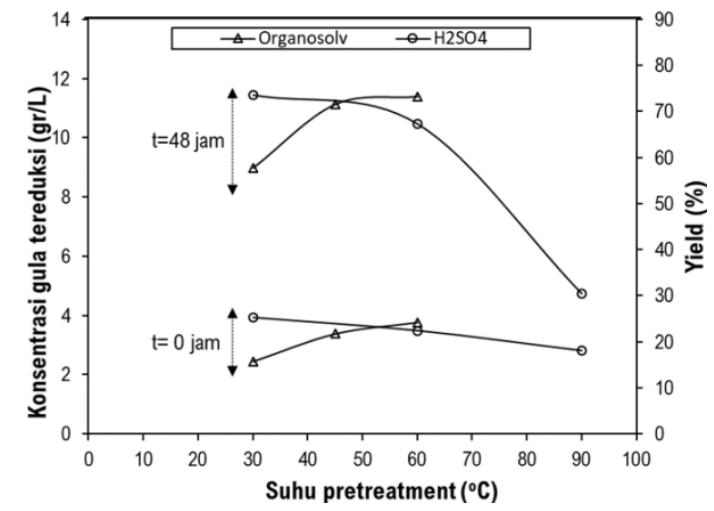

(b)

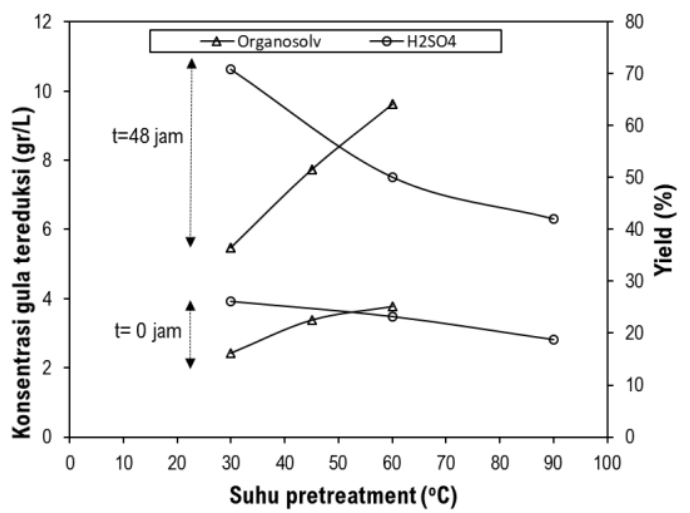

(d)

Gambar 2. Pengaruh waktu $(a, c)$ dan suhu $(b, d)$ pretreatment terhadap gula tereduksi yang dihasilkan sebelum dan setelah proses hidrolisa enzimatik dengan Aspergillus niger $(a, b)$ dan oryzae $(c, d)$ selama 48 jam 
Tabel 1. Kajian teknis berbagai metode pretreatment

\begin{tabular}{|c|c|c|c|}
\hline \multirow[b]{2}{*}{ Pretreatment } & \multicolumn{3}{|c|}{ Kajian Teknis } \\
\hline & Penanganan bahan kimia & $\begin{array}{c}\text { Penanganan saat } \\
\text { Pretreatment }\end{array}$ & Pencucian \\
\hline $\begin{array}{l}\text { Organosolv } \\
(\text { Etanol }+ \\
\left.\mathrm{H}_{3} \mathrm{COONa}\right)\end{array}$ & $\begin{array}{l}\text { Cukup mudah dalam penyimpanan, } \\
\text { etanol tetap dalam keadaan layak } \\
\text { dipakai walaupun disimpan dalam } \\
\text { waktu yang lama, dan disarankan } \\
\text { untuk menyimpan ditempat yang } \\
\text { rapat dan dijauhkan dari benda } \\
\text { yang mudah terbakar karena etanol } \\
\text { mudah untuk menguap. Sedangkan } \\
\mathrm{CH}_{3} \mathrm{COONa} \text { yang berbentuk } \\
\text { padatan, cukup dengan dihindarkan } \\
\text { kontak dengan air dan udara }\end{array}$ & $\begin{array}{l}\text { Perlu pengawasan yang teliti } \\
\text { karena titik didih metanol } \\
\text { berada pada suhu } 60^{\circ} \mathrm{C}\end{array}$ & $\begin{array}{l}\text { Lebih mudah untuk } \\
\text { dinetralkan, tidak } \\
\text { memerlukan air } \\
\text { dalam jumlah banyak } \\
\text { dalam proses } \\
\text { pencucian untuk } \\
\text { menetralkan pH. }\end{array}$ \\
\hline $\mathrm{H}_{2} \mathrm{SO}_{4}$ & $\begin{array}{l}\text { Memerlukan teknik khusus dalam } \\
\text { penyimpanan, tidak dianjurkan } \\
\text { untuk menyimpannya dalam waktu } \\
\text { lama karena berpengaruh terhadap } \\
\text { kualitasnya. }\end{array}$ & $\begin{array}{l}\text { Titik didih tinggi, yaitu } \\
290^{\circ} \mathrm{C} \text {, namun larutan asam } \\
\text { dapat mengalami } \\
\text { penguraian apabila terkena } \\
\text { panas dan mengeluarkan } \\
\text { gas } \mathrm{SO}_{2} \text {. }\end{array}$ & $\begin{array}{lr}\text { Memerlukan } & \text { volume } \\
\text { air yang } & \text { cukup } \\
\text { banyak } & \text { untuk } \\
\text { menetralkan } & \mathrm{pH} \\
\text { setelah proses. } & \end{array}$ \\
\hline
\end{tabular}

Tabel 2. Kajian ekonomi berbagai metode pretreatment

\begin{tabular}{lcc}
\hline \multicolumn{1}{c}{ Parameter } & $\begin{array}{c}\text { Pretreatment asam } \\
\left(\mathrm{H}_{2} \mathrm{SO}_{4}\right)\end{array}$ & $\begin{array}{c}\text { Pretreatment organosolv } \\
\left(\mathrm{Etanol}+\mathrm{CH}_{3} \mathrm{COONa}\right)\end{array}$ \\
\hline Yield yang dihasilkan (optimum) & $78 \%$ & $74 \%$ \\
Waktu proses & 30 menit & 90 menit \\
Kebutuhan air (proses pencucian) & $180 \mathrm{~mL} / \mathrm{gr}$ bahan baku & $60 \mathrm{~mL} / \mathrm{gr} \mathrm{bahan} \mathrm{baku}$ \\
Kebutuhan reagen & $0.05 \mathrm{~mL} / \mathrm{gr}$ bahan baku & $9 \mathrm{~mL} / \mathrm{gr}$ bahan baku \\
\hline
\end{tabular}

\section{KESIMPULAN}

Penelitian untuk mengetahui efektifitas proses pretreatment dan hidrolisa untuk mengkonversi lignoselulosa yang terkandung dalam kulit singkong menjadi bentuk gula sederhana yang nantinya dapat digunakan sebagai bahan baku bioetanol telah dilaksanakan. Metode pretreatment asam $\left(\mathrm{H}_{2} \mathrm{SO}_{4}\right)$ dan organosolv (Etanol $+\mathrm{CH}_{3} \mathrm{COONa}$ ) terbukti dapat meningkatkan yield gula tereduksi hingga 50\% dibandingkan dengan proses hidrolisa tanpa pretreatment. Yield hingga 78\% dapat diperoleh pada proses pretreatment asam $\left(\mathrm{H}_{2} \mathrm{SO}_{4}\right)$ suhu $30^{\circ} \mathrm{C}$, waktu 30 menit yang dilanjutkan dengan hidrolisa enzimatik dengan Aspergillus niger selama 48 jam. Peningkatan yield pada proses pretreatment organosolv (optimum $74 \%$ pada suhu $30^{\circ} \mathrm{C}$, waktu 90 menit) masih dapat dilakukan dengan meningkatkan waktu operasi dan meningkatkan suhu operasi. Namun peningkatan suhu maupun penambahan waktu operasi berpengaruh terhadap analisa teknis dan ekonomis dari proses. Secara teknis, pretreatment organosolv lebih mudah dilakukan terutama pada proses dengan kondisi operasi atmosferik 
dibandingkan dengan pretreatment asam karena sifat bahan kimia yang digunakan dan penanganannya. Secara ekonomis, pretreatment asam lebih baik untuk diaplikasikan dibandingkan pretreatment organosolv, hal ini dikarenakan bahan kimia yang digunakan lebih sedikit secara kuantitas dan lebih murah. Selain itu, yield proses pretreatment asam lebih tinggi apabila dibandingkan pada waktu proses yang sama.

\section{UCAPAN TERIMAKASIH}

Terimakasih yang sebesar-besarnya
disampaikan kepada Dinas Pendidikan,
Pemerintah Provinsi Jawa Tengah atas pendanaan
riset ini melalui Program Penelitian Dosen Muda
(PPDM).

\section{DAFTAR PUSTAKA}

Andersen, N. 2007. Enzymatic Hydrolysis of Cellulose Experimental and Modeling Studies., Ph.D. Thesis BioCentrum-DTU, Technical University of Denmark.

Artiyani, A. 2011. Bioetanol dari limbah kulit singkong melalui proses hidrolisis dan fermentasi dengan saccharomyces cerevisiae. Tesis. Program Magister Jurusan Teknik Lingkungan, Fakultas Teknik Sipil dan Perencanaan, Institut Teknologi Sepuluh Nopember.

Badan Pengkajian dan Penerapan Teknologi [BPPT]. 2018. Outlook Energi Indonesia 2018. Pusat Pengkajian Industri Proses dan Energi (PPIPE). Badan Pengkajian dan Penerapan Teknologi (BPPT). ISBN 978-602-1328-05-7

Badan Pusat Statistik [BPS]. 2018. Provinsi Jawa Tengah dalam Angka 2018. www.bps.go.id.

Hikmiyati, N., \& Yanie, N.S. 2010. Pembuatan bioetanol dari limbah kulit singkong melalui proses hidrolisa asam dan enzimatis. Skripsi. Jurusan Teknik Kimia, Fak. Teknik, Universitas Diponegoro.

Juwita, A.A., \& Susilowati, C. 2011. Bioetanol dari ampas dan kulit singkong. Skripsi. Jurusan Teknik Kimia, Fak. Teknik, Universitas Diponegoro.

Kongkiattikajorn, J., 2012., Ethanol Production from Dilute-Acid Pretreated Cassava Peel by Fed-Batch Simultaneous Saccharification and
Fermentation., International Journal of the Computer, the Internet and Management, 20 (2): 22-27

Kongkiattikajorn, J. \& Sornvoraweat, B., 2011., Comparative Study of Bioethanol Production from Cassava Peels by Monoculture and CoCulture of Yeast. Kasetsart Journal (Nat. Sci.), 45:268-274

Murtianto, B.W. \& Aria Chandra, B. 2008. Production of bioethanol from cassava peel waste (cpw) by using sweet corn enzyme powder. Semesta Bilingual Boarding School.

Olanbiwoninu, A.A, \& Odunfa, S.A., 2012, Enhancing the Production of Reducing Sugars from Cassava Peels by Pretreatment Methods., International Journal of Science and Technology, 2(9):650-657.

Quesada-Medina, J., López-Cremades, F.J. \& Olivares-Carrillo, P., 2010. Organosolv extraction of lignin from hydrolyzed almond shells and application of the $\delta$-value theory. Bioresource technology, 101(21), pp.8252-8260.

Geetha, G.S., \& Krishnan, A.N.G. 2009. Diluted acid hydrolysis and steam explosion of Manihot esculenta peeling waste for bio ethanol production. Centre for Environmental Studies, Anna University.

Sun, F.F., Tang, S., Liu, R., Tang, Y., Wang, R., Zhang, Z., Gao, Z., Li, H., Li, C \& Xiao, Z. 2016. Biorefining fractionation of the Camellia oleifera Abel. hull into diverse bioproducts with a two-stage organosolv extraction. Industrial Crops and Products. 94:790-799.

Wyman, C.E., Decker, S.R., Himmel, M.E., Brady, J.W., Skopec, C.E., \& Viikari, L., 2006., Hydrolysis of Cellulose and Hemicellulose. Chapter book.

Xu, G., Wang, A., Pang, J., Zheng, M., Yin, J., \& Zhang, T. 2015. Remarkable effect of extremely dilute $\mathrm{H}_{2} \mathrm{SO}_{4}$ on the cellulose conversion to ethylene glycol. Applied Catalyst A: General. 502: 65-70.

Zhao, X., Cheng, K. \& Liu, D. 2009. Organosolv pretreatment of lignocellulosic biomass for enzymatic hydrolysis., Applied Microbiology and Biotechnology. 82:815-827

Zhang, Y.H.P., Cui J., Lynd, L.R. \& Kuang, L.R. 2006. A transition from cellulose swelling to cellulose dissolution by o-phosphoric acid: evidence from enzymatic hydrolysis and supramolecular structure. Biomacromolecules. 7: 644-648. 
Zhang, Z., Harrison, M.D., Rackemann, D.W., Dohertya, W.O.S \& O'Haraa, I.A. 2016.

Organosolv pretreatment of plant biomass for enhanced enzymatic saccharification. Green Chemistry. 18(2):360-381 